\title{
BISNIS ONLINE: PREFERENSI KONSUMEN TERHADAP LAYANAN ONLINE FOOD DELIVERY
}

\author{
Nadiah Arum Mindarti \\ Made Siti Sundari \\ Sugeng Hariadi \\ Fakultas Bisnis dan Ekonomika Universitas Surabaya, Indonesia \\ Email: nadiaharum21@gmail.com
}

\begin{abstract}
This research studies the factors that influence consumers in using online food delivery services. The variables used are Time Saving Orientation, Price Saving Orientation, and Behavior Intention to OFD Services. The questionnaire is used in the data collection process. Questions in this study were published online and offline. Online distribution is done through Google Form and offline distribution is done by distributing it to students of the University of Surabaya. A total of 208 valid questionnaires were collected to be submitted using Structural Equation Modeling (SEM) data processing with SmartPLS software. Time Saving Orientation and Price Saving Orientation have positive and significant effect on Behavior Intention Towards OFD Services which support $t$-statistics of 3,562 \& 3,272 and P-Values of 0,000. The more culinary entrepreneurs who use ecommerce, the more transactions will occur, so it will increase the GRDP which will ultimately increase economic growth.
\end{abstract}

Keywords: Behavioral, Delivery, Orientation, Tim, Price

\section{PENDAHULUAN}

Pada zaman modern seperti sekarang ini, hampir semua kalangan dan segala segi umur seperti anak-anak, orang dewasa, bahkan lansia sudah sangat akrab dengan yang namanya internet. Pesatnya kemajuan teknologi memberikan banyak sekali manfaat dan memudahkan manusia untuk melakukan berbagai aktivitas. Banyak sekali kegiatan yang dilakukan dengan menggunakan internet, mulai dari mencari informasi / berita terbaru, berbelanja kebutuhan sehari-hari, membeli baju, memesan makanan, hingga berkomunikasi dengan orang lain. Seiring berkembangnya dunia perdagangan elektronik, hal itu diikuti dengan kian meningkatnya aktivitas jual beli secara online. Hal itu berdampak pada segala sesuatu yang berbasis online, contohnya saja seperti membeli baju secara online, memesan makanan secara online, membeli kebutuhan sehari-hari di toko online / e-commerce, dsb.

Tidak hanya membeli baju atau kebutuhan sehari-hari secara online saja yang sedang booming belakangan ini, namun penggunaan layanan online food delivery (OFD) kini kian meningkat peminatnya. Layanan online food delivery (OFD) kini sangat pesat perkembangannya dan kian meningkat peminatnya, mulai dari kalangan pelajar hingga pekerja. Layanan online food delivery (OFD) merupakan solusi bagi orang-orang yang 
ingin menghemat waktu dan tenaga agar tetap bisa melakukan aktivitas lain namun tetap efektif dan efesien. Oleh karena itu penulis ingin meneliti tentang preferensi konsumen terhadap layanan online food delivery (OFD).

Tujuan penelitian ini adalah yang pertama (1) untuk mengetahui pengaruh Time Saving Orientation terhadap Behavioral Intention Towards OFD Services dan yang kedua (2) untuk mengetahui pengaruh Price Saving Orientation terhadap Behavioral Intention Towards OFD Services. Penelitian ini diharapkan dapat menambah wawasan baik secara teori maupun praktek serta dapat menjadi bahan referensi bagi peneliti lain yang tertarik untuk mendalami penelitian yang sejenis khususnya dalam bidang bisnis internasional \& diharapkan bisa memberikan manfaat terhadap para praktisi atau pengusaha bisnis internasional dalam memahami bagaimana preferensi konsumen terhadap layanan online food delivery (OFD).

E-business, e-commerce, e-sourcing, dan e-fulfilment adalah beberapa istilah terbaru yang dikutip dalam literatur. Secara umum, mereka merujuk pada bisnis yang dilakukan secara elektronik (Huff, et.al., 2000). Menurut (Turban, et.al., 1999), ebusiness meliputi transaksi yang dilakukan di pasar elektronik, layanan kepada konsumen, kolaborasi dengan mitra bisnis dan hubungan intra-organisasi. E-business adalah bagian dari konteks ekonomi yang lebih luas yang bertanggung jawab atas transformasi radikal dalam bisnis dan mencakup jaringan digital dan infrastruktur komunikasi. Selain itu, e-business menyediakan platform global tempat individu dan organisasi berinteraksi, berkomunikasi, berkolaborasi, dan memperoleh informasi. Sistem berbasis web e-business semakin mewakili keunggulan kompetitif bagi perusahaan dan telah mengalami perubahan organisasi yang besar (Currie \& Parikh, 2006)

Seperti yang dikemukakan oleh teori preferensi belanja, alasan untuk berbelanja di outlet ritel melampaui pembelian. Ada motif fungsional dan nonfungsional yang mendorong pilihan outlet ritel serta proses berbelanja. Beberapa peneliti (Tauber, 1972; Bloch, et.al., 1994; Bellenger \& Korgaonkar, 1980; Lunt \& Livingstone, 1992; Jarratt \& Polonsky, 1993) telah menunjukkan peran motif sosial dalam proses berbelanja. Tauber (1972) mengidentifikasi lima jenis motif dari sifat sosial: (1) pengalaman sosial di luar rumah, (2) komunikasi dengan orang lain yang memiliki minat yang sama, (3) ketertarikan kelompok sebaya (4) mendapatkan peningkatan status dan wewenang dan (5) kesenangan tawar-menawar.

Salah satu fitur yang ditawarkan oleh Go-Jek dan GrabFood untuk memenuhi kebutuhan konsumen adalah fitur GrabFood dan GoFood, fitur ini memberikan kemudahan bagi konsumen untuk memperoleh makanan dan minuman yang diinginkan dari berbagai pilihan restoran hanya melalui media smartphone tanpa harus mengunjungi toko makanan dan minuman tersebut. Selain memberi kemudahan kepada konsumen, online food delivery service ini juga memberikan keuntungan bagi pelaku bisnis, membantu untuk memberikan akses yang selebar-lebarnya kepada mereka yang ingin berinovasi kuliner tanpa modal yang besar. Pelaku bisnis khususnya pengusaha kuliner yang mengadopsi online food delivery service, tidak harus memiliki karyawan khusus dan kendaraan tersendiri untuk layanan pengantaran kepada konsumen. Sehingga mereka tidak perlu mengeluarkan biaya tambahan untuk gaji karyawan, juga tidak memerlukan space atau tempat khusus dalam menggunakan layanan tersebut.

Sejak 1980-an segmen makanan dibawa pulang dan juga pengiriman makanan telah mengalami pertumbuhan yang sangat pesat di Inggris. Banyaknya pilihan dan jenis makanan yang ada, hal itu membuat pasar makanan dibawa pulang dan juga pengiriman makanan menjadi sangat terfragmentasi (Alreck \& Settle, 2002; Ball, 1999). Pelanggan berfikir bahwa menggunakan layanan online food delivery sangat menguntungkan karena pelayanan mereka dalam hal kecepatan, kemudahan, dan juga ketepatan pesanan (Verma, 
et.al., 2009). Presentase dari pengiriman makanan menunjukkan bahwa sekitar $70 \%$ dari orderan yang ada adalah berasal dari sektor rumah tangga, maka dapat diambil kesimpulan bahwa target pasar untuk pengiriman makanan adalah lebih berfokus pada sektor rumah tangga.

$\mathrm{H}_{1}$ : Diduga Time Saving Orientation (TSO) berpengaruh secara signifikan terhadap Behavioral Intention Towards OFD Services.

Harga didefinisikan sebagai nilai moneter yang harus diberikan sebagai imbalan terhadap suatu produk atau layanan dalam perjanjian pembelian (Nagle, et.al., 2010). Dengan adanya potongan harga, konsumen dapat menghemat uang dari potongan tersebut, karena mereka sangat memperhatikan jumlah uang yang dapat mereka simpan melalui potongan harga tersebut (Darke, et.al., 1995). Tversky \& Kahneman (1981) melakukan penelitian yang mengungkapkan bahwa dengan adanya potongan harga produk yang diberikan oleh beberapa toko, konsumen tidak keberatan dan bersedia untuk melakukan perjalanan ekstra. Penelitian tentang efektivitas potongan harga juga membuktikan bahwa dengan adanya potongan harga maka akan menambah nilai dan membuat semakin menarik penawaran produk yang akan dirasakan oleh konsumen karena hal itu adalah indikasi bahwa harga tersebut adalah penawaran yang lebih baik (Thaler 2008).

$\mathrm{H}_{2}$ : Diduga Price Saving Orientation (PSO) berpengaruh secara signifikan terhadap Behavioral Intention Towards OFD Services.

Suatu adopsi terhadap teknologi dapat ditentukan oleh niat perilaku yang dimana hal itu adalah kombinasi dari sikap seseorang dan manfaat yang dapat dirasakan (Davis, 1989). Niat perilaku sangat dapat diprediksi oleh sikap karena memiliki efek positif yang signifikan. Menurut Ajzen \& Fishbein (1977), sikap seseorang dapat mempengaruhi respons terhadap stimulan. Dikatakan bahwa seseorang yang memiliki sikap yang mendukung tindakan akan lebih cenderung melakukan perilaku tertentu (Kuo \& Yen, 2009; Rezaei, et.al., 2016).

Pendekatan alternatif, yang mengarah pada hasil yang sama, pertama kali diusulkan oleh Paul Samuelson pada akhir 1940-an. Pendekatan ini, yang oleh Samuelson disebut teori preferensi yang diungkapkan, mendefinisikan prinsip rasionalitas yang didasarkan pada perilaku yang diamati dan kemudian menggunakan prinsip ini untuk memperkirakan fungsi utilitas individu (Nicholson, 1995). Dalam pengertian ini, seseorang yang mengikuti prinsip rasionalitas Samuelson berperilaku seolah-olah dia memaksimalkan fungsi utilitas yang tepat dan menunjukkan efek substitusi negatif. Karena pendekatan Paul Samuelson memberikan wawasan tambahan yang cukup besar ke dalam model pilihan konsumen.

Pendekatan preferensi yang diungkapkan bernilai sebagai sarana untuk memeriksa apakah pilihan individu konsisten dengan asumsi teori konsumen. Analisis preferensi yang diungkapkan dapat membantu dalam memahami implikasi pilihan yang harus dibuat konsumen dalam keadaan tertentu (Pindyck \& Rubinfeld, 2009).

\section{METODE PENELITIAN}

Karakteristik populasi dalam penelitian ini adalah pengguna layanan online food delivery. Kuesioner digunakan dalam proses pengumpulan data untuk penelitian ini. Kuesioner dalam penelitian ini disebarkan secara online dan offline. Penyebaran online dilakukan melalui Google Form dan penyebaran offline dilakukan dengan cara 
disebarkan pada mahasiswa/i Universitas Surabaya pengguna layanan online food delivery. Penelitian ini menggunakan skala likert 5, skala likert 5 atau 7 poin lebih mungkin menghasilkan skor rata - rata yang sedikit lebih tinggi dibandingkan dengan skala 10 poin, yang membuat membandingkan data menjadi proses yang jauh lebih mudah (Dawes, 2007). Pada awal data yang terkumpul adalah 221 responden namun karena ada beberapa data yang dianggap tidak dapat digunakan, sehingga hanya tersisa 208 responden.

Metode pengolahan data dalam penelitian ini menggunakan Structural Equation Modelling (SEM). SEM memungkinan peneliti untuk menilai baik hubungan kasual antar indikator / variabel dan hubungan kasual lebih lanjut antara variabel laten (Gudergan, et.al., 2009). Algoritma PLS memungkinkan setiap indikator untuk bervariasi dalam berapa banyak konstribusi untuk skor komposit variabel laten (Chin, et.al., 2003). Dengan demikian, penelitian ini menggunakan PLS-SEM untuk menilai pengukuran dan model struktural menggunakan perangkat lunak SmartPLS.

\section{HASIL DAN PEMBAHASAN}

Nilai composite reliability setiap variabel menunjukkan nilai yang lebih besar dari 0,7 , yang artinya bahwa variabel-variabel tersebut reliable atau dapat dikatakan handal. Bagian terakhir adalah nilai AVE setiap variabel juga menunjukkan nilai di atas 0,5. Dapat disimpulkan bahwa ketiga variabel tersebut telah memenuhi standar (Tabel 1).

Tabel 1 Uji Validitas dan Reliabilitas

\begin{tabular}{lcccc}
\hline & $\begin{array}{c}\text { Cronbach's } \\
\text { Alpha }\end{array}$ & rho_A & $\begin{array}{l}\text { Composite } \\
\text { Reliability }\end{array}$ & AVE \\
\hline $\begin{array}{l}\text { Behavioral } \\
\begin{array}{l}\text { Intention Towards } \\
\text { OFD Services }\end{array}\end{array}$ & 0,829 & 0,850 & 0,897 & 0,744 \\
\hline $\begin{array}{l}\text { Price Saving } \\
\text { Orientation }\end{array}$ & 0,712 & 0,720 & 0,838 & 0,633 \\
\hline $\begin{array}{l}\text { Time Saving } \\
\text { Orientation }\end{array}$ & 0,723 & 0,725 & 0,878 & 0,783 \\
\hline
\end{tabular}

Sumber: Data penelitian tahun 2019, diolah menggunakan SmartPLS

Tabel 2 Hasil Outer Loadings

\begin{tabular}{|c|c|c|c|}
\hline & $\begin{array}{c}\text { Behavioral } \\
\text { Intention } \\
\text { Towards OFD } \\
\text { Services }\end{array}$ & $\begin{array}{c}\text { Price Saving } \\
\text { Orientation }\end{array}$ & $\begin{array}{l}\text { Time Saving } \\
\text { Orientation }\end{array}$ \\
\hline BI1 & 0,891 & & \\
\hline $\mathrm{BI} 2$ & 0,843 & & \\
\hline $\mathrm{BI} 3$ & 0,852 & & \\
\hline PSO1 & & 0,808 & \\
\hline PSO2 & & 0,755 & \\
\hline PSO3 & & 0,822 & \\
\hline TSO1 & & & 0,891 \\
\hline TSO2 & & & 0,879 \\
\hline
\end{tabular}

Sumber: Data penelitian tahun 2019, diolah menggunakan SmartPLS

Hasil outer loadings menggambarkan seberapa besar korelasi antara variabel laten dan indikator yang ada. Berdasarkan Tabel 2, nilai setiap variabel menunjukkan nilai di 
atas 0,7 . Semakin tingginya nilai outer loadings maka dapat diartikan bahwa semakin bagus korelasi antara variabel laten dan indikator yang ada. Dapat disimpulkan bahwa indikator yang ada di penelitian ini adalah valid.

Tabel 3 Nilai $R$-Square

\begin{tabular}{lc}
\hline & R-Square \\
\hline $\begin{array}{l}\text { Behavioral Intention Towards } \\
\text { OFD Services }\end{array}$ & 0,353 \\
\hline
\end{tabular}

Sumber: Data penelitian tahun 2019, diolah menggunakan SmartPLS

Tujuan dilakukannnya pengujian terhadap inner model adalah untuk mengetahui korelasi antar variabel laten. Berdasarkan Tabel 3, terdapat satu nilai $\mathrm{r}-$ square yaitu Behavioral Intention Towards OFD Services yang diperoleh yaitu sebesar 35,3\%.

Tabel 4 Path Coefficient

\begin{tabular}{cccccc}
\hline & $\begin{array}{c}\text { Original } \\
\text { Sample (O) }\end{array}$ & $\begin{array}{c}\text { Sample } \\
\text { Mean }(\mathrm{M})\end{array}$ & $\begin{array}{c}\text { Standard } \\
\text { Deviation } \\
\text { (STDEV) }\end{array}$ & T Stat & $\begin{array}{c}\mathrm{P} \\
\text { Values }\end{array}$ \\
\hline PSO > BI & 0,464 & 0,464 & 0,064 & 7,272 & 0,000 \\
TSO > BI & 0,239 & 0,249 & 0,067 & 3,562 & 0,000 \\
\hline Sumber: Data penelitian tahun 2019, diolah mengounakan SmartPLS
\end{tabular}

Untuk mengetahui pengaruh variabel eksogen terhadap variabel endogen maka dilakukan pengujian path coefficient. Untuk meminimalkan ketidaknormalan data dalam penelitian makan dilakukan bootstrapping. Hipotesis penelitian dapat diterima dengan ketentuan nilai $t$-statistik $\geq t$-tabel dan $\mathrm{P}-$ Values $<0,05$. Berdasarkan Tabel 4 , hipotesis penelitian dapat diterima karena hasil dari nilai $t$-statistik adalah 7,272 dan 3,562 dan juga nilai $\mathrm{P}$ - Values nya adalah 0,000 .

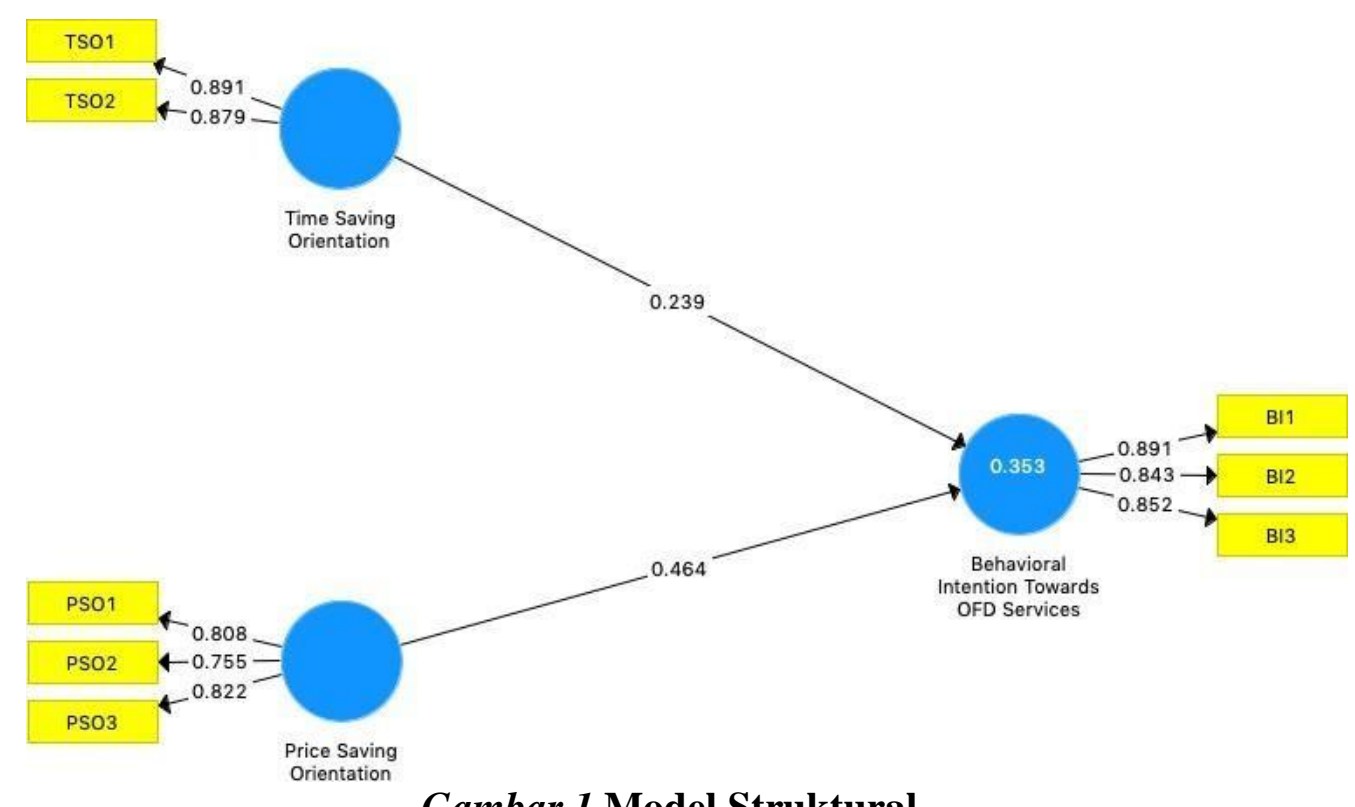

Gambar 1 Model Struktural

Sumber: Data penelitian 2019, diolah menggunakan SmartPLS 
Gambar 1 adalah model struktural penelitian ini yang diolah menggunakanSmartPLS. Dalam model struktural tersebut terdapat tiga variabel yaitu Time Saving Orientation, Price Saving Orientation, dan Behavioral Intention Towards OFD Services Time Saving Orientation mempengaruhi secara positif terhadap Behavioral Intention Towards OFD Services (Tabel 4). Besar koefisien pengaruh Time Saving Orientation terhadap Behavioral Intention Towards OFD Services adalah 0,239 berdasarkan kolom original sample yang artinya adalah adanya pengaruh positif. Semakin tinggi Time Saving Orientation, maka akan semakin tinggi pula Behavioral Intention Towards OFD Services. Hipotesis penelitian dapat diterima denganketentuan nilai $t$-statistik $\geq t$-tabel dan $\mathrm{P}-$ Values $<0,05$. Berdasarkan Tabel 4 , hipotesispenelitian dapat diterima karena hasil dari nilai $t$-statistik adalah 3,562 dan juga nilai $\mathrm{P}$ - Values nya adalah 0,000 .

Dapat disimpulkan bahwa Time Saving Orientation mempengaruhi secara siginifikan terhadap Behavioral Intention Towards OFD Services dan tidak ada nilai error. Maka hipotesis pertama $\left(\mathrm{H}_{1}\right)$ dapat diterima. Diterimanya hipotesis pertama $\left(\mathrm{H}_{1}\right)$ mendukung penelitian yang dilakukan oleh Alreck \& Settle (2002) yang menulis kesimpulan bahwa skor aktivitas secara signifikan terkait dengan pembelian katalog untuk menghemat waktu, tetapi tidak dengan pembelian internet untuk menghemat waktu.

Price Saving Orientation mempengaruhi secara positif terhadap Behavioral Intention Towards OFD Services (Tabel 4). Besarnya koefisien pengaruh Price Saving Orientation terhadap Behavioral Intention Towards OFD Services adalah 0,464 berdasarkan kolom original sample yang artinya adalah adanya pengaruh positif.

Semakin tinggi Price Saving Orientation, maka akan semakin tinggi pula Behavioral Intention Towards OFD Services. Hipotesis penelitian dapat diterima dengan ketentuan nilai $t$-statistik $\geq t$-tabel dan $\mathrm{P}-$ Values $<0,05$. Berdasarkan Tabel 4 , hipotesis penelitian dapat diterima karena hasil dari nilai $t$-statistik adalah 3,272 dan juga nilai $\mathrm{P}$ Values nya adalah 0,000 .

Dapat disimpulkan bahwa Price Saving Orientation mempengaruhi secara siginifikan terhadap Behavioral Intention Towards OFD Services dan tidak ada nilai error. Maka hipotesis kedua $\left(\mathrm{H}_{2}\right)$ dapat diterima. Diterimanya hipotesis kedua $\left(\mathrm{H}_{2}\right)$ mendukung penelitian yang dilakukan Escobar-Rodríguez \& Carvajal-Trujillo (2014) yang menulis kesimpulan bahwa penghematan harga adalah faktor yang memainkan peran penting sebagai pendorong langsung niat pembelian tiket online LCC.

Hal ini berarti bahwa semakin besar penghematan uang (atau kemungkinan mendapatkan produk / layanan yang lebih baik dengan harga tertentu) dan semakin besar manfaat yang diterima konsumen yang dapat mereka peroleh dengan membeli langsung melalui situs web LCC, semakin kuat niat mereka akan untuk menggunakan situs web LCC untuk pembelian tiket pesawat di masa depan.

\section{KESIMPULAN}

Berdasarkan hasil pengujian data dan uji hipotesis yang dilakukan menggunakan SmartPLS, didapatkan kesimpulan bahwa yang pertama (1) Time Saving Orientation berpengaruh positif dan siginifikan terhadap Behavioral Intention Towards OFD Services yang ditunjukkan oleh nilai $t$-statistik sebesar 3,562 dan $\mathrm{P}$ - Values sebesar 0,000 dan yang kedua (2) Price Saving Orientation berpengaruh positif dan siginifikan terhadap Behavioral Intention Towards OFD Services yang ditunjukkan oleh nilai $t$-statistik sebesar 3,272 dan $\mathrm{P}$ - Values sebesar 0,000. 


\section{DAFTAR PUSTAKA}

Ajzen, I., \& Fishbein, M., 1977, Attitude-Behavior Relations: A Theoretical Analysis And Review Of Empirical Research. 84, 888-918.

Alreck, P. L., \& Settle, R. B., 2002, The Hurried Consumer: Time-Saving Perceptions Of Internet And Catalogue Shopping. Journal Of Database Marketing, 10, 25-35.

Ball, S., 1999, Whither The Small Independent Take-Away? 101, 715-723.

Bellenger, D. N., \& Korgaonkar, P. K., 1980, Profiling The Recreational Shopper,.

Bloch, P. H., Ridgway, N. M., \& Dawson, S. A., 1994, The Shopping Mall As Consumer Habitat . Journal Of Retailing, 70, 23-42.

Chin, W., Marcolin, B., \& Newsted, P., 2003, A Partial Least Squares Latent Variable Modeling Approach For Measuring Interaction Effects: Results From A Monte Carlo Simulation Study And An Electronic-Mail Emotion/Adoption Study. 2, 189-217.

Currie, W., \& Parikh, M. A., 2006, Value Creation In Web Services: An Integrative Model. Strategic Information Systems, 15, 153-174.

Darke, P., Freedman, J., \& Chaiken, S., 1995, Percentage Discounts, Initial Price, And Bargain Hunting: A Heuristic Approach To Price Search Behavior. 80.

Davis, F. D., 1989, Perceived Usefulness, Perceived Ease Of Use, And User Acceptance Of Information Technology. 13, 319-340.

Dawes, J., 2007, Do Data Characteristics Change According To The Number Of Scale Points Used? 50, 61-77.

Escobar-Rodríguez, T., \& Carvajal-Trujillo, E., 2014, Online Purchasing Tickets For Low Cost Carriers: An Application Of The Unified Theory Of Acceptance And Use Of Technology (UTAUT) Model. Tourism Management, 43, 70-88.

Gudergan, S., Ringle, C., Wende, S., \& Will, A., 2008, Confirmatory Tetrad Analysis In PLS Path Modeling. 61, 1238-1249.

Huff, S., Wade, M., Parent, M., Schneberger, S., \& Newson, P., 2000, Case In Electronic Commerce.

Jarrat, D. G., \& Polonsky, M. J., 1993, Causal Linkages Between Psychographic And Demographic Determinants Of Outshopping Behaviour. The International Review Of Retail, Distribution And Consumer Research, 3, 303-319. Journal Of Retailing, 56, 77-92.

Kuo, Y., \& Yen, S., 2009, Towards An Understanding Of The Behavioral Intention To Use 3G Mobile Value-Added Services. 25, 103-110.

Lunt, P. K., \& Livingstone, S., 1992, Mass Consumption And Personal Identity: Everyday Economic Experience.

Nagle, T., Hogan, J., \& Zale, J., 2010, The Strategy And Tactics Of Pricing: A Guide To Profitable Decision Making.

Pindyck, R. S., \& Rubinfeld, D. L., 2009, Microeconomics. Pearson International Edition. Nicholson, W., 1995, Microeconomic Theory: Basic Principles And Extensions.

Rezaei, S., Shahijan, M., Amin, M., \& Ismail, W., 2016, Determinants Of App Stores Continuance Behavior: A PLS Path Modelling Approach. 15, 408-44-.

Tauber, E. M., 1972, Marketing Notes And Communications. Journal Of Marketing, 4, 46-49.

Thaler, R. H., 2008, Mental Accounting And Consumer Choice. Marketing Science, 27, $15-25$.

Turban, E., Lee, J., King, T., \& Chung, H., 1999, Electronic Commerce: A Managerial And Social Networks Perspective. 8th Ed. New Jersey: Prentice Hall.

Tversky, A., \& Kahneman, D., 1981, The Framing Of Decisions And The Psychology Of Choice. Science, 211, 453-458.

Verma, R., Dixon, M., \& Kimes, S., 2009, Customer Preferences And Use Of Technology-Based Innovations In Restaurants: A Best-Worst Choice Analysis. 


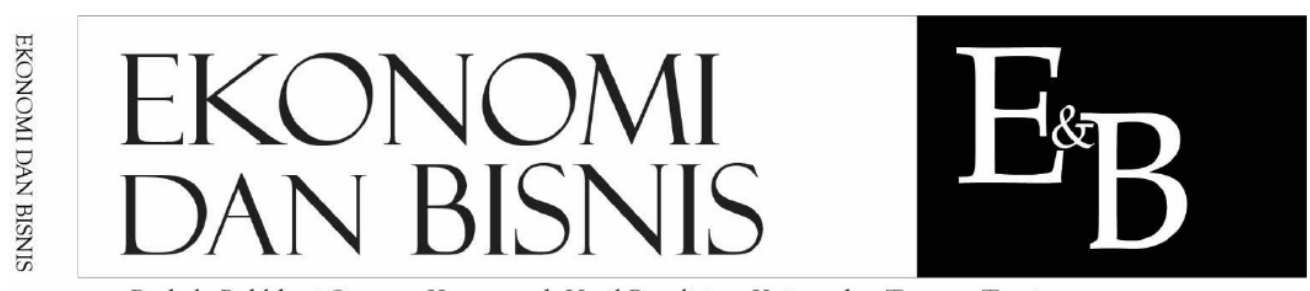

Berkala Publikasi Gagasan Konseptual, Hasil Penelitian, Kajian, dan Terapan Teori

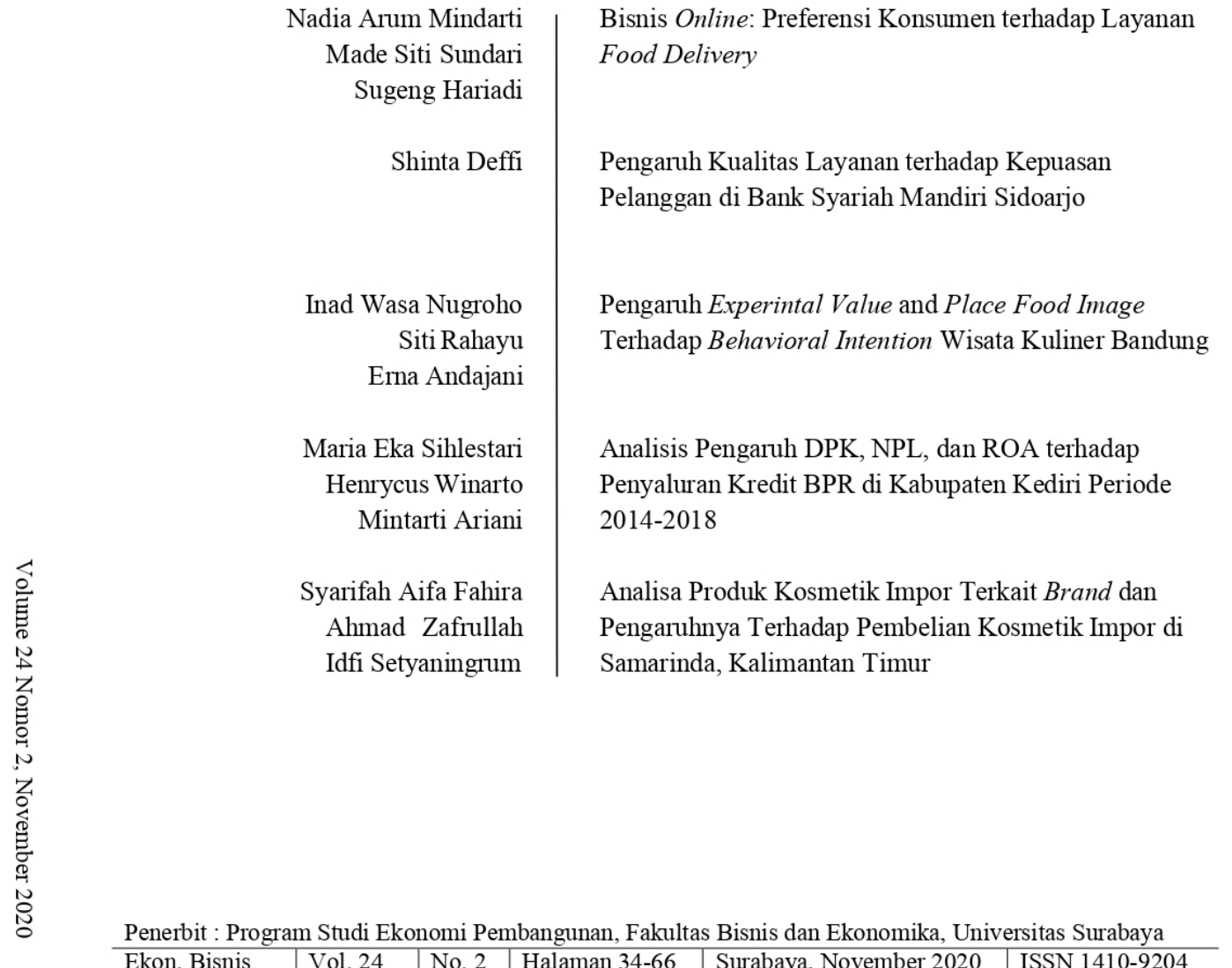

Penerbit : Program Studi Ekonomi Pembangunan, Fakultas Bisnis dan Ekonomika, Universitas Surabaya \begin{tabular}{l|l|l|l|l|l} 
Ekon. Bisnis & Vol. 24 & No. 2 & Halaman 34-66 & Surabaya, November 2020 & ISSN 1410-9204
\end{tabular} 


\section{$\underset{\text { DAN BISNIS }}{\text { EKONOMI }} \mathrm{E}_{\mathrm{B}}$}

Berkala Publikasi Gagasan Konseptual, Hasil Penclitian, Kajian, dan Terapan Teon

Q Terakreditasi Sinta-5 oleh KEMRESTEKDIKT No. 30/E/KPT/2019 masa berishu sejak 11 November 2019 - 10 Nov
Home Current Archives Announcements About -
Home / Editorial Team
Editorial Team
EDITORIAL TEAM

Ketua Penyunting (Chief Editor):

Dr. Sugeng Hariadi, S.E., M.Si | SINTA ID : $\underline{6014665}$

Penyunting (Editor):

- Dra.ec. Mintarti Ariani, M.Si | SINTA ID : 6016861

- Dr. Draec. Made Siti Sundari, M.Si | SINTA ID : $\underline{6696190}$

- Firman Rosjadi, S.E., M.TISINTA ID : $\underline{6015330}$

Penyunting Pelaksana (Executing Editor):

- Olivia Tanaya, S.E., M.B.A.

- Joshi Maharani Wibowo, S.E., M.E.

- Cynthia Yohanna Kartikasari, S.E., M.SE

- Yohana Wahyu Prasetyowatie, S.E., M.SE

\section{\% Additional Menu :}

Editorial Team

Reviewer List

Focus \& Scope

Duties Of Authors

Duties Of Reviewers

Publication Ethics

Authors Guidelines

Author Fees

Open Access Policy

Screening for Plagiarism

Copyright Notice

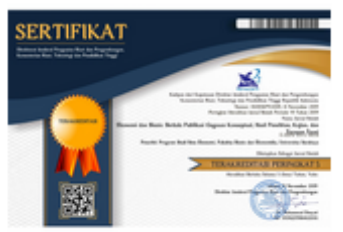

Most read last week

PENGADAAN BARANG

PUBLIK: STUDI KASUS FLY

OVER PASAR KEMBANG

SURABAYA

O 21 
Vol. 24 No. 2 (2020): Ekonomi dan Bisnis: Berkala Publikasi Gagasan Konseptual, Hasil Penelitian, Kajian, dan Terapan Teori

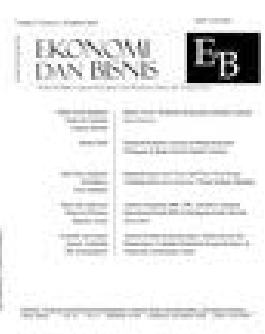

Berkala Publikasi Gagesan Konseptual, Hasil Penelitien, Kajian, dan Terapan Teori di terbitkan olsh Program Soudi Imu Ekonomi, Falkultes Bisnis dan Ekonomika, Universitas Surabaya D-ISSN 1410-9204, q-1SSN $2655-8958$ DOI htrp: //doi.org/10.24123/iab.v24i2

rublished: $2011-11-2 y$

Artickes

BISNIS ONLINE: PREFERENSI KONSUMEN TERHADAP LAYANAN ONLINE FOOD DELIVERY

Nadiah Arum Mindarti, Made Siti Sundari, Sugeng Hariadi

A Abstract Views: 17 Nadiah Arum Mindarti, Made Siti Sunderi, Sugeng Hariadi (Bahasa Indonssia)

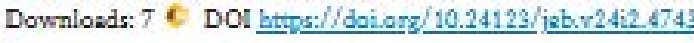

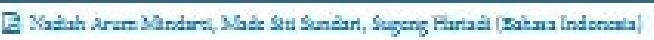

\section{PENGARUH KUALTTAS LAYANAN TERHADAP KEPUASAN PELANGGAN DI BANK SYARIAH} MANDIRI SIDOAR JO

D

4 Abstract Views: 16 a Shinte Deffi (Behese Indonesia) Downloads: 4 C DOI htres/doiorg/10.24123 jeb. $\times 24 i 2.4746$

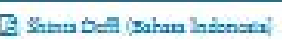

PENGARUH EXPERIENTAL VALUE DAN PLACE FOOD IMAGE TERHADAP BEHAVIORAL INTENTION WISATA KULINER BANDUNG

Inad Wase Nugroho, Siti Rahayu, Ema Andajeni

4 Abstract Visws: $23 \Leftrightarrow$ Inad Wasa Nugrobo, Siti Rahaya, Erna Andaiani (Bahasa Indonssia) Downlaadse $s C$ DOI htras/doiorg/10.24123/isb.V24i2.47.47

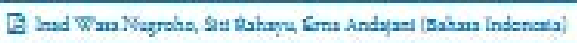

ANALISIS PENGARUH DPK, NPL, DAN ROA TERHADAP PENYALURAN KREDIT BPR DI KABUPATEN KEDIRI PERIODE 2014-2018

Maria Eka Siblestari, Henrycus Winarto, Mintarti Ariani

4 Abetract Views: is a Maria Eka Sihlestari, Hennecus Winarto, Mintarti Ariani (Bahesa Indonesia) Downloads: 5 C DOI htrpg://doiorg/10.24123/isb.r24i2.4745

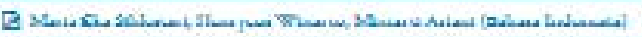

ANALISIS PRODUK KOSMETIK IMPOR TERKAIT BRAND DAN PENGARUHNYA TERHADAP PEMBELLAN KOSMETIK IMPOR DI SAMARINDA, KALIMANTAN TIMUR

Syarifah Aifa Fahira, Ahmad Zafrullah, Idf Setyaningrum

A Abatract Visws: 16 Syarifah Aifa Fahira, Ahmad Zafrallah, Idfi Setyaningrum (Bahasa Indoneria) Downloads: $3 \&$ DOI https://doi.org/10.24123/isb.v2 $24 i 2.4749$

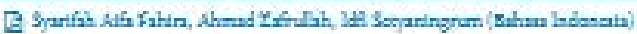




\section{SERTIFIKAT}

Direktorat Jenderal Penzualan Riset dan Pengembangan.

Kementerian Riset, Teknologi dan Pendidikan Tinggi

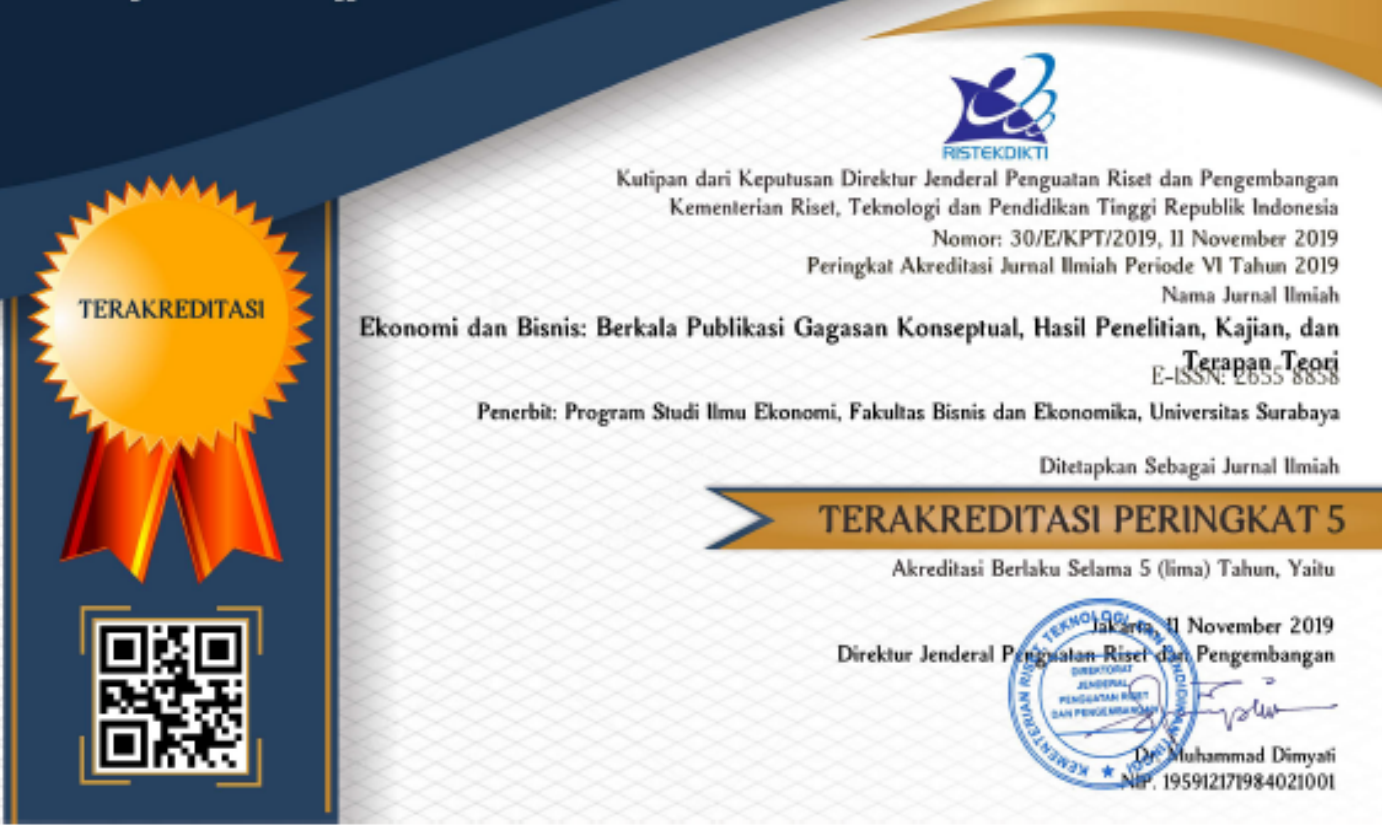

